9. Razumova H. Methodical approach to polydiagnostic evaluation of the national economy development. The potential of modern science: collective monograph. Editor: Babych M.M. London, United Kingdom: Sciemcee Publishing. 2019. Р. 173-182.

10.Разумова Г. В. Підхід до оцінки регуляторної політики та іiі впливу на розвиток економіки. Економічний простір. Дніпро: ПДАБА, 2019. № 142. С. 78-87. DOI 10.30838/P.ES.2224.260219.78.380.

\title{
References
}

1. Pohribniak, M. A. (2008). Mekhanizm derzhavnoi rehuliatornoi polityky u sferi hospodarskoi diialnosti [Mechanism of Regulatory Policy in Economic Activity]. avtoref. dys. ... kand. nauk z derzh. upr.: 25.00.02. 20. [in Ukrainian].

2. Tolmacheva, H., Liashenko, V., Khakhulin, V., Yakubiak, O. (2013). Rehuliatorna polityka ta udoskonalennia biznes-seredovyshcha $\mathrm{v}$ Ukraini [Regulatory policy and improving the business environment in Ukraine]. Bulletin of economic science of Ukraine, 2 (24), 156-165. [in Ukrainian].

3. Osadcha, N. V. (2014) Zminy rehuliatornoi polityky Ukrainy v umovakh pidpysannia asotsiatsii $\mathrm{z}$ Yevropeiskym Soiuzom [Changes in the regulatory policy of Ukraine in the context of the association with the European Union]. Bulletin of economic science of Ukraine, 3, 71-75. [in Ukrainian].

4. Yuldashev, O. Kh. (2005). Problemy vdoskonalennia derzhavnoi rehuliatornoi polityky v Ukraini [The problems of state regulatory policy in Ukraine]. Kyiv: MAUP, 336. [in Ukrainian].

5. Kolupayeva, I. V. (2013). Derzhavna rehuliatorna polityka: sutnist ta pryntsypy formuvannia [State regulatory policy: essence and principles of formation]. The problems of economy, 4, 99-107. [in Ukrainian].

6. Sheverdina, O. V. (2016). Derzhavne rehuliuvannia u sferi hospodarskoi diialnosti: pravovyi analiz i tendentsii [State regulation of economic activity: legal analysis and trends]. Legal scientific electronic journal. (n.d.). www.lsej.org.ua. Retrieved from http://www.lsej.org.ua/6_2016/29.pdf. [in Ukrainian].

7. OECD (2018), OECD Regulatory Policy Outlook 2018, OECD Publishing, Paris, https://doi.org/10.1787/9789264303072-en.

8. Zakon Ukrainy «Pro zasady derzhavnoi rehuliatornoi polityky u sferi hospodarskoi diialnosti» [The Law of Ukraine «On the Principles of Regulatory Policy in Economic Activity»]. (n.d.). zakon.rada.gov.ua. Retrieved from https://zakon.rada.gov.ua/laws/show/1160-15 [in Ukrainian].

9. Razumova, H. (2019). Methodical approach to polydiagnostic evaluation of the national economy development. The potential of modern science. London, United Kingdom: Sciemcee Publishing. Vols. 2, 173182.

10. Razumova, H. V. (2019). Pidkhid do otsinky rehuliatornoi polityky ta yii vplyvu na rozvytok ekonomiky [Approach to regulatory policy evaluation and its effects on economic development]. Economic space, 142, 78-87. DOI 10.30838/P.ES.2224.260219.78.380 [in Ukrainian].

Стаття надійшла до редакції 31.07.2019 р.

УДК 338.45(477):662.76]:330.341.1:336

Новосад Оксана, аспірант,

Східносвропейський національний університет імені Лесі Українки, кафедра аналітичної економіки та природокористування; м. Луцьк, ORCID ID: 0000-0001-7156-643X e-mail: novosad_ox@ukr.net

https://doi.org/10.29038/2411-4014-2019-03-30-37

\section{РОЛЬ ІННОВАЦІЙНО-ІНВЕСТИЦІЙНОї ДІЯЛЬНОСТІ ДЛЯ ГАЗОТРАНСПОРТНИХ ПІДПРИЕМСТВ РЕГІОНУ}

В статті розглянуто загальні концепції інноваційно-інвестиційної діяльності, охарактеризовано структуру та складові політики держави щодо впровадження інноваційно-інвестиційних змін, з’ясовано роль та значення 
інноваційно-інвестиційних процесів на газотранспортних підприємствах. Проаналізовано фактори внутрішнього та зовнішнього впливів на формування інноваційно-інвестиційного середовища газотранспортних підприємств. Окреслено теоретичні та практичні напрями у вдосконаленні соціального та організаційного ефекту на підприємствах газотранспортної сфери на інноваційно-інвестиційних засадах.

Ключові слова: інноваційно-інвестиційна політика, інновації, конкуренція, газотранспортне підприємство, промисловість, газотранспортна інфраструктура.

Новосад Оксана, аспирант,

Восточноевропейський национальный университет имени Леси Украинки, кафедра аналитической экономики и природопользования, г. Луцк

\section{РОЛЬ ИННОВАЦИОННО-ИНВЕСТИЦИОННОЙ ДЕЯТЕЛЬНОСТИ НА ГАЗОТРАНСПОРТНЫХ ПРЕДПРИЯТИЯХ РЕГИОНА}

В статье рассматриваются общие концепции инновационно-инвестиционной деятельности, охарактеризована структура и составляющие политики государства по внедрению инновационноинвестиционных изменений, выяснена роль и значение инновационно-инвестиционных процессов на газотранспортных предприятиях. Проанализированы факторы внутреннего и внешнего воздействия на формирование инновационно-инвестиционной среды газотранспортных предприятий.

Определены теоретические и практические направления усовершенствования социального и организационного эффекта предприятий газотранспортной сферы на инновационно-инвестиционных принципах.

Ключевые слова: инновационно-инвестиционная политика, инновации, конкуренция, газотранспортное предприятие, промышленность, газотранспортная инфраструктура.

Postgraduate, Lesya Ukrainka Eastern European National University, Department of Analytical Economics and Nature Management, Lutsk

\section{THE ROLE OF INNOVATION AND INVESTMENT ACTIVITY FOR REGION GAS TRANSPORT ENTERPRISES}

The article deals with the general concepts of innovation and investment activity, describes the structure and components of the state policy regarding the implementation of innovation and investment changes, the role and significance of innovation and investment processes in gas transport enterprises are determined. The factors of internal and external influences on the formation of innovation and investment environment of gas transport enterprises are analyzed. The theoretical and practical directions in improving the social and organizational effect at the enterprises of the gas transportation sphere on the basis of innovation-investment principles are outlined.

Key words: innovation and investment policy, innovations, competition, gas transportation company, industry, gas transportation infrastructure.

Актуальність теми дослідження. Технологічна база газотранспортних підприємств України сьогодні характеризується значним зношенням основних засобів та його стрімким наростанням за існуючих у глобальному економічному просторі високих темпів науково-технічного прогресу. За таких умов нагальною є потреба активізації інноваційної діяльності для технічного переоснащення та модернізації об'єктів газотранспортної системи, що вимагає залучення значних обсягів інвестиційних ресурсів. Усе це зумовлює необхідність глибокого аналізу сутності, напрямів та тенденцій розвитку інноваційно-інвестиційної діяльності у газотранспортній сфері та виявлення проблем розвитку газотранспортних підприємств.

Дослідженням науково-методичних засад управління інноваційно-інвестиційними процесами присвячено праці багатьох зарубіжних і вітчизняних вчених: В. Александрової, І. Алексєєва, О. Бороніна, Я. Витвицького, В. Геєця, Л. Гітмана, В. Дорофеєва, І. Єгорова, Л. Канторовича, А. Яковлєва та ін. 
Водночас потребують узагальнення питання формування цілей і пріоритетів інноваційного розвитку газотранспортних підприємств, тарифоутворення на їх послуги, удосконалення методичних підходів до визначення ефективності інноваційно-інвестиційних проектів, створення відповідного організаційно-економічного механізму сприяння інноваційно-інвестиційній діяльності у газотранспортній сфері. Актуальність цих проблем зумовила вибір теми роботи, визначила ії мету i завдання.

Мета і завдання дослідження. Метою статті є розробка теоретико-практичних рекомендацій щодо ролі та значення інноваційно-інвестиційних процесів на газотранспортних підприємствах.

\section{Основні завдання дослідження:}

- розширити понятійно-категоріальний апарат, що стосується управління інноваційноінвестиційними процесами на газотранспортних підприємствах;

- удосконалити класифікацію основних факторів, що впливають на процеси інноваційного розвитку газотранспортних підприємств;

- з'ясувати роль та значення інновацій у діяльності газотранспортних підприємств.

Об'скт дослідження. Інноваційно-інвестиційні процеси на газотранспортних підприємствах.

Предмет дослідження. Теоретичні та практичні засади формування інноваційно-інвестиційних процесів на газотранспортних підприємствах.

Виклад основного матеріалу дослідження. На сьогодні концепція інноваційного розвитку стала визначальною в економічній політиці провідних фірм та розвинутих держав світу. Це можна пояснити тим, що саме інновації дозволяють краще зрозуміти природу економічних явищ, що спостерігаються і надати пояснення тим тенденціям, що стали домінуючими у соціальноекономічному поступі, особливо у розвинених країнах світу.

Досягнуті в Україні за час незалежності темпи економічного зростання та пожвавлення в економіці і сфері науки ще не дозволяють на сьогодні забезпечити пріоритетний розвиток науковотехнічної та інноваційної сфер. За даними Держкомстату України, наукоємність промислового виробництва України не перевищує $0,4 \%$, що на порядок менше світового рівня. Близько $90 \%$ продукції, що виробляється в Україні, не має відповідного науково-технологічного забезпечення. Неефективною та затратомісткою залишається структура виробництва [1].

В таких умовах та враховуючи негативний вплив на вітчизняну економіку світової економічної кризи, стержнем сучасної української моделі конкурентоспроможності економіки має стати реалізація інноваційної моделі структурної перебудови економіки, а в подальшому - стратегії економіки знань.

Для здійснення структурної перебудови економіки за інноваційною мо-деллю необхідно, перш за все, переорієнтувати державну політику з фінансової донорської підтримки окремих підприємств і галузей виробництва на створення привабливих умов і середовища для інвестування інноваційної діяльності та розповсюдження інновацій у всіх секторах вітчизняної економіки [2].

Головна мета національної інноваційної системи - тісна взаємодія між всіма учасниками комерціалізації знань/технологій. Формування інноваційної системи передбачає вдосконалення системи генерації знань, формування цілісної інноваційної інфраструктури та системи трансферу технологій, підвищення ефективності управління інтелектуальною власністю, стимулювання попиту на інновації.

Необхідно зазначити, що центральне місце у сучасній інноваційній системі належить великим фірмам, які є основним двигуном економічного розвитку. Розвиток сучасної ринкової економіки тісно пов'язаний з ринковим суперництвом цих транснаціональних компаній, які $є$ головними учасниками ринку. Умовою для виживання таких компаній на ринку $є$ постійне вдосконалення технологій виробництва, інноватизація управління, вдосконалення товарів та послуг.

До таких фірм, безумовно, належать і газотранспортні підприємства України.

Особливістю сучасного стану системи газозабезпечення України $є$ те, що вона не може існувати як ізольована замкнута система, орієнтована виключно на внутрішній ринок. Основними причинами цього є:

- невідповідність існуючої ресурсної бази природного газу обсягам його внутрішнього споживання, а також суттєве неспівпадання обсягів видобування газу із потребами економіки та 
побутово-комунальної сфери. В силу цих чинників система газозабезпечення України потребує зовнішнього ресурсного забезпечення через імпорт газу з території інших країн;

- невідповідність існуючих газотранспортних потужностей внутрішнім потребам газопостачання. Тут потрібно виділити два аспекти, зокрема наяв-ність надлишкових транспортних потужностей призводить до зростання витрат та зниження ефективності транспортування газу. Особливо це стосується трубопроводів і напрямків транспортування, які характеризуються низьким коефіцієнтом завантаження транспортних потужностей. Разом з тим, наявність резерву потужностей, особливо зорієнтованих у напрямку «схід-захід», дозволяє здійснювати на комерційних умовах транзит газу, що є, без сумніву, привабливим позитивним чинником [3, с. 28-29].

Отже, можна однозначно стверджувати, що розвиток газотранспортних підприємств України у відповідності із вимогами сьогодення неможливий без пріоритетної уваги до його інноваційної складової.

Можна виділити декілька груп факторів, що мають безпосередній вплив на процеси інноваційного розвитку газотранспортних підприємств.

Перша група - фактори прямої дії, пов'язані з конкретними заходами державної економічної політики. До них належать: нестабільність законодавчої бази, надмірне оподаткування, високі митні збори, бюрократизм і некомпетентність місцевої влади, недостатні страхові гарантії держави, нерозвиненість інфраструктури. Їхня особливість полягає в тому, що вони є найбільш вагомими причинами несприятливого інвестиційного клімату в Україні. Утім їх усунення цілком залежить від бажання держави, яка здатна відносно швидко впливати на них і у такий спосіб змінювати інвестиційне становище в тій або іншій галузі. Найбільш значимим у цій групі є фактор стабільності законодавства. Так, іноземні бізнесмени не вважають поганими українські закони, але скаржаться на частий їх перегляд, що не дозволяє реально передбачити результати інвестування. Невизначеність, у свою чергу, призводить до небажання вкладати гроші в економіку [4].

Інший значний фактор цієї групи - надмірність оподаткування. Так, на сьогоднішній день податки в Україні вилучають приблизно 80 \% прибутку підприємств, що не стимулює іноземних інвесторів. Це обумовлює необхідність проведення політики подальшого скорочення розмірів оподаткування.

До другої групи належать «системні» фактори, які склалися в результаті формування специфічних відносин між партнерами по бізнесу в Україні. Така система сформувалася в перехідний період в результаті швидкої, часто незаконної приватизації державної власності, активної участі в цих процесах кримінальних кіл. До системних факторів належать такі, як: злочинність і корупція, неплатежі партнерів по бізнесу, брак надійних партнерів.

Третя група - це фактори, які не тільки впливають на інвестиційний клімат, а й залежать від нього. До них належать високий рівень інфляції, недостатня купівельна спроможність населення, обмеженість послуг місцевих банків, брак ринкової інформації, кадрові проблеми, монополізація ринків товарів і послуг, брак виробничих потужностей. Ці фактори взаємозалежні з інвестиційним кліматом. Наприклад, проблеми, пов'язані з інфляцією, недо-статньою купівельною спроможністю населення, обмеженими можливостями банківської сфери, браком необхідних кадрів, монополізацією ринку, браком виробничих потужностей вирішуються шляхом інвестування за рахунок джерел зовнішнього і внутрішнього капіталу [5].

Позитивними факторами впливу на інноваційну діяльність (як зовнішні-ми, так і внутрішніми) $є$ імпульси, що спонукають підприємства до впровад-ження інновацій. Внутрішні позитивні фактори це фізичний знос обладнання, необхідність знизити енерговитрати, прагнення розширити виробничі потужності.

Зовнішніми позитивними факторами можна вважати:

- ініціативи, що виникають в корпораціях і коригуються ринковими відносинами. Головним зовнішнім імпульсом до інновацій на підприємствах $\epsilon$ ринковий попит. Якщо інновації, що генеруються зсередини, $є$ процесними, то ринкова орієнтація підприємств спрямовує їх на продуктові інновації;

- конкуренцію, яка є основним стимулом до впровадження інновацій. Відкриття національного ринку для імпорту стимулює підвищення якості та розширення асортименту продукції, змушує 
продавати ï за нижчими цінами, ніж імпортні аналоги, посилює конкуренцію і з боку місцевих виробників;

- тиск з боку партнерів по бізнесу;

- тиск з боку споживачів;

- тиск з боку зарубіжних партнерів.

Всі фактори, що впливають на інноваційну діяльність, діють комплексно i $\epsilon$ взаємообумовленими. Взаємообумовленість факторів, що призводять до появи інновацій, ускладнює виділення серед них пріоритетних.

Системне бачення в управлінні інноваційними процесами дозволяє впроваджувати їх у найбільш повному обсязі. У свою чергу, системний підхід базується на таких основних принципах:

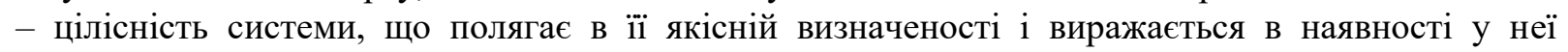
специфічних або інтегральних властивостей, які об'єднують частини системи в єдине ціле, зумовлюють появу в неї нових властивостей внаслідок зв'язків між ії компонентами.

- ієрархічність - означає, що на будь-яких вертикальних або горизонтальних рівнях системи має забезпечуватися ієрархічна взаємодія між іiі компонентами (етапами, стадіями технологічного ланцюжка, підрозділами, окремими працівниками);

- адаптивність - означає пристосованість системи до змін. Наприклад, пристосованість виробничого апарату до нової техніки, технології, пристосованість персоналу до інноваційних, організаційних та інших змін;

- керованість - означає упорядкованість інформаційних і матеріальних потоків, регулярність виконання функцій за командами керівної ланки (керуючої підсистеми), а також відсутність збоїв і простоїв у роботі устаткування, синхронність різних стадій виробничих процесів;

- оптимальність - це головна властивість системи, яка означає можливість системи у найкращий спосіб реалізовувати покладені на неї завдання і функції на основі концентрації зусиль всіх іiі елементів.

Незважаючи на різноманіття організаційних видів систем управління інноваційною діяльністю, будь-яка 3 них повинна мати такі складові: 1) об’єкти інновацій (явища, процеси, види господарської діяльності тощо); 2) інноваційні ресурси (матеріальні та нематеріальні); 3) сприйнятливе до інновацій внутрішнє середовище; 4) управління інноваційним процесом (інноваційний менеджмент), що здійснюється колективом фахівців з економіки, фінансів, маркетингу, менеджменту, соціології, технологій та інших галузей знань.

Також, система інноваційного управління повинна містити елементи, що забезпечують іiі функціонування: 1) вхід у систему - ресурси, вимоги, інформаційні потоки, що надходять до системи ззовні у певній сукупності та послідовності; 2) зовнішне середовище - сукупність зовнішніх факторів, вплив яких необхідно враховувати при реалізації інноваційних проектів; 3) вихід системи, тобто те, заради чого вона функціонує, - економічний, соціальний і інший ефект.

Інноваційна діяльність підприємства має враховувати особливості газотранспортної галузі і передбачати концентрацію інвестицій на одному або невеликій кількості проектів для мінімізації ризиків і забезпечення високої ефективності у майбутньому. Концентрація інвестицій дозволяє скорочувати терміни реалізації проектів.

В епоху інтелектуалізації економіки сучасні інновації, зокрема об’єкти права інтелектуальної власності, науково-технологічні розробки слугують однією з головних рушійних сил суспільного виробництва, розбудови держави, розвитку суспільства.

Тому науково-технологічна, інноваційна, інвестиційна політика на цьому етапі мають бути нерозривними, складати одне ціле, оскільки будь-яка довгострокова інвестиційна діяльність одночасно є також інноваційною і фінансові інвестиції спрямовуються, перш за все, на створення нового інтелектуального продукту та запровадження інновацій виходячи 3 потреб економіки, а інтелектуальні інвестиції сприяють інноваційному розвитку всіх іï сфер.

Отже, інноваційні процеси тісно пов'язані із інвестиційними, але для підвищення ефективності інвестицій на газотранспортних підприємствах необхідно запроваджувати відносно новий та специфічний вид інновацій - операційні інновації (як різновид організаційних інновацій).

Як вже зазначалось вище, інновації $є$ результатом інноваційної діяльності. Інноваційна діяльність - діяльність, спрямована на використання i комерціалізацію результатів наукових 
досліджень і розробок, що зумовлює випуск на ринок нових конкурентоздатних товарів і послуг. Суб’єктами інноваційної діяльності можуть бути фізичні та юридичні особи України та іноземних держав, особи без громадянства, об'єднання юридичних та фізичних осіб, які проводять в Україні інноваційну діяльність.

Необхідно зазначити, що інноваційна діяльність згідно із Законом України «Про інноваційну діяльність» [6] - одна 3 форм інвестиційної діяльності, що здійснюється з метою впровадження досягнень науково-технічного прогресу у виробництво і соціальну сферу. Як вже зазначалось вище, ці два види діяльності $є$ нерозривно пов'язані і у сучасній науці інвестиції розглядаються як головний фактор інноваційного розвитку суспільства [7, с.177-187]. Безумовно, що ця діяльність має свою специфіку у кожному секторі економіки і це стосується газотранспортних підприємств.

Можна так визначити інноваційно-інвестиційну діяльність газотранспортних підприємств - це цілеспрямований процес змін, що органічно поєднує процеси створення інновацій, їх фінансове забезпечення і практичну реалізацію в умовах функціонування газотранспортної системи України. Сутнісне наповнення інноваційно-інвестиційної діяльності газотранспортних підприємств визначається їі залежністю від сучасного рівня науково-технічного прогресу у цій сфері, наявності інвестицій та існуючих стратегічних пріоритетів, системоорганізуючого впливу глобалізації та існуючої у конкретний момент часу політичної ситуації, а також системи сформованих моральних, духовних і культурних цінностей суспільства.

У практичній діяльності газотранспортних підприємств інновації $є$ пере-творенням досягнень науково-технічного прогресу в реальний процес, втілений у нові технології та послуги. Вони мають суттєві відмінності від виробничих процесів, що здійснюються на підприємстві. До відмінностей інноваційно-інвестиційного процесу від виробничого можна віднести: багатоваріантність та невизначеність шляхів досягнення цілей; неможливість детального планування та оріснтацію на прогнозні оцінки; труднощі у комерціалізації результатів наукового пошуку; підвищений ризик інноваційно-інвестиційної діяльності.

Виходячи із цих особливостей та на основі проведеного вище аналізу необхідно визначити цілі та пріоритети інноваційно-інвестиційної діяльності газотранспортних підприємств.

Формування такої системи цілей у сфері управління газотранспортними підприємствами необхідно здійснювати з урахуванням тенденцій геополітич-ного, макроекономічного, соціального і науково-технічного розвитку країни. Ця система цілей має враховувати та органічно доповнювати більш загальну систему цілей, визначених Енергетичною стратегією України на період до 2030 року, якою задекларовано наступні стратегічні цілі [8]:

- створення умов для постійного та якісного задоволення попиту на енергетичні продукти;

- визначення шляхів і створення умов для безпечного, надійного та сталого функціонування енергетики та їі максимально ефективного розвитку;

- забезпечення енергетичної безпеки держави;

- зменшення техногенного навантаження на довкілля та забезпечення цивільного захисту у сфері техногенної безпеки ПЕК;

- зниження питомих витрат у виробництві та використанні енерго-продуктів за рахунок раціонального їх споживання, впровадження енергозбе-рігаючих технологій та обладнання, раціоналізації структури суспільного виробництва і зниження питомої ваги енергоємних технологій;

- інтеграція Об‘ єднаної енергосистеми України до європейської енерго-системи з послідовним збільшенням експорту електроенергії, зміцнення позицій України як транзитної держави нафти і газу.

На основі цих цілей та цілей газотранспортної галузі [9] можна так визначити пріоритети інноваційного розвитку газотранспортних підприємств:

- забезпечення надійного та стабільного газопостачання України;

- диверсифікація джерел та шляхів постачання газу в Україну;

- нарощування науково-технічного потенціалу газотранспортних підприємств 3 метою підвищення ефективності функціонування всіх виробничих об'єктів;

- енергозаощадження та зниження енергоємності виробничих процесів на всіх стадіях видобування, переробки, транспортування, зберігання, розподілу та використання природного газу;

- реконструкція та модернізація існуючих виробничих потужностей; 
- широке впровадження організаційних та управлінських ноу-хау у практичну діяльність;

- зменшення техногенного навантаження на довкілля.

Для реалізації встановлених цілей та пріоритетів інноваційно-інвестиційної діяльності газотранспортних підприємств України необхідне суттєве вдосконалення існуючого механізму управління на цих підприємствах.

Ситуація в інноваційній сфері в Україні $є$ складною. Рівень інноваційної активності у промисловості залишається невисоким протягом багатьох років. У країні спостерігається брак не тільки традиційних технологічних інновацій, а і організаційних інновацій, які здатні суттєво підвищити ефективність діяльності на тій самій технологічній основі. У таких умовах та враховуючи негативний вплив на вітчизняну економіку світової економічної кризи, стержнем сучасної української моделі конкурентоспроможності економіки має стати реалізація інноваційної моделі структурної перебудови економіки. Для досягнення цієї цілі необхідно, перш за все, переорієнтувати державну політику з фінансової донорської підтримки окремих підприємств і галузей виробництва на створення привабливих умов i середовища для інвестування інноваційної діяльності та розповсюдження інновацій у всіх секторах вітчизняної економіки, у тому числі і у газотранспортній cферi.

Інноваційно-інвестиційна діяльність базується на певних принципах. Сутністю інноваційноінвестиційної діяльності газотранспортних підприємств $є$ цілеспрямований процес змін, що органічно поєднує процеси створення інновацій, їх фінансове забезпечення і практичну реалізацію в умовах функціонування газотранспортної системи України. Змістовне наповнення інноваційноінвестиційної діяльності газотранспортних підприємств визначається ії залежністю від сучасного рівня науково-технічного прогресу у цій сфері, наявністю інвестицій та існуючих стратегічних пріоритетів, системо-організуючого впливу глобалізації та існуючої у конкретний момент часу політичної ситуації, а також системи сформованих моральних, духовних і куль-турних цінностей суспільства. Визначено цілі та пріоритети інноваційно-інвестиційної діяльності газотранспортних підприємств. Формування цієї сис-теми цілей і пріоритетів здійснено з урахуванням світових тенденцій геополі-тичного, макроекономічного, соціального, науково-технічного розвитку та цілей, визначених Енергетичною стратегією України на період до 2030 року.

Формування механізму управління інноваційно-інвестиційними проце-сами $\mathrm{y}$ сфері трубопровідного транспортування та розподілу природного газу неможливе без вирішення низки важливих питань, пов'язаних із тарифоутворенням на послуги газотранспортних підприємств. Встановлено, що існуюча система тарифоутворення та чинна практика державного регулювання газотранспортних тарифів в Україні не відповідають потребам інноваційного розвитку газотранспортних підприємств, не дозволяють залучити необхідний інноваційно-інвестиційний капітал для реконструкції та модернізації виробничих об'єктів, не відповідають інтересам потенційних інвесторів, не сприяють підвищенню ефективності функціонування суб'єктів природних монополій, до яких відносяться і газотранспортні підприємства.

Тому для підвищення достовірності інвестиційних рішень у газотранспортній сфері доцільним $\epsilon$ ïx удосконалення шляхом урахування специфіки газотранспортної галузі, більш коректного врахування фактора часу, економічних вигод і ефектів, що супроводжують інвестування.

\section{Джерела та література}

1. Гораль Л. Т. Аналіз макросередовища функціонування газотранспортних підприємств в контексті використання їх потенціалу. Соиіально-економічні проблеми сучасного періоду України. Львів, 2015. Вип. 1 (111). С. 122-126.

2. Загвойська Л. Д., Маселко Т. Є., Якуба М. М. Економічний аналіз інвестиційних проектів : навч. посіб. Львів : Афіша, 2006. 320 с.

3. Дзьоба О. Г. Управління трансформаціями та розвитком системи газозабезпечення: монографія. ІваноФранківськ : ІФНТУНГ, 2012. 352 с.

4. Майорова Т. В. Інвестиційна діяльність : навч. посіб. Київ : ЦУЛ, 2003. 376 с.

5. Новосад О.В., Стрішенець О. М., Коротя М. І. Диверсифікація інноваційних заходів на газорозподільних підприємствах України в контексті європейського досвіду. Економічний часопис 
Східноєвропейського національного університету імені Лесі Украйнки : журнал / уклад. Любов Григорівна Ліпич, Мирослава Богданівна Кулинич. Луцьк : Вежа-Друк, 2018. № 2 (14). С. 7-12.

6. Про інноваційну діяльність : Закон України від 04.07.2002 р. № 40-IV. Відомості Верховної Ради Украӥни. 2002. № 36. Ст. 266.

7. Фатхутдинов Р. А. Инновационный менеджмент. Учебник. 4-е изд. СПб. : Питер, 2003. 400 с.

8. Енергетична стратегія України на період до 2030 року. URL : http://zakon.rada.gov.ua/signal/ kr06145a.doc.

9. Хвесик М. А., Степаненко А. В., Обиход Г. О. Інноваційно-інвестиційна і технологічна безпека трансформації регіональних економічних систем : монографія. Київ : Науково-виробниче підприємство «Видавництво «Наукова думка» НАН України», 2013. 487 с.

\section{References}

1. Horal L. T. (2015). Analiz makroseredovyshcha funktsionuvannia hazotransportnykh pidpryiemstv v konteksti vykorystannia yikh potentsialu [An analysis of macromedia of functioning of gas-transport enterprises is in the context of the use of their potential]. Sotsialno-ekonomichni problemy suchasnoho periodu Ukrainy Socio-economic problems of modern period of Ukraine, 1(111), 122-126 [in Ukrainian].

2. Zahvoiska L. D., Maselko T. Ye., Yakuba M. M. (2006). Ekonomichnyi analiz investytsiinykh proektiv [Economic analysis of investment projects]: navch. posib. Lviv : Afisha, 320 [in Ukrainian].

3. Dzoba O. H. (2012). Upravlinnia transformatsiiamy ta rozvytkom systemy hazozabezpechennia [Management transformations and development of the system of providing with gas]: monohrafiia. Ivano-Frankivsk : IFNTUNH, 352 [in Ukrainian].

4. Maiorova T. V. (2003). Investytsiina diialnist [Investment activity] : navch. posib. Kyiv : TSUL, 376 [in Ukrainian].

5. Novosad O.V., Strishenets O. M., Korotia M. I. (2018). Dyversyfikatsiia innovatsiinykh zakhodiv na hazorozpodilnykh pidpryiemstvakh Ukrainy $\mathrm{v}$ konteksti yevropeiskoho dosvidu [Diversification of innovative events is on the gas-distributing enterprises of Ukraine in the context of європейського experience]. Ekonomichnyi chasopys Skhidnoievropeiskoho natsionalnoho universytetu imeni Lesi Ukrainky - Economic magazine of the east Europe national university of the name of Lesia Ukrainian : zhurnal / uklad. Liubov Hryhorivna Lipych, Myroslava Bohdanivna Kulynych. Lutsk : Vezha-Druk, 2 (14), 7-12 [in Ukrainian].

6. Pro innovatsiinu diialnist : Zakon Ukrainy vid 04.07.2002 r. № 40-IV [About innovative activity : there is Law of Ukraine from 04.07.2002 № 40 - IV]. (2002). Vidomosti Verkhovnoi Rady Ukrainy - Lists of Supreme soviet of Ukraine, 36. St. 266 [in Ukrainian].

7. Fatkhutdynov R. A. (2003). Ynnovatsyonnыi menedzhment [Innovative management]. Uchebnyk. 4-e yzd. Pyter, 400 [in Ukrainian].

8. Enerhetychna stratehiia Ukrainy na period do 2030 roku [Power strategy of Ukraine on a period 2030 to]. Retrieved from http://zakon.rada.gov.ua/signal/ kr06145a.doc [in Ukrainian].

9. Khvesyk M. A., Stepanenko A. V., Obykhod H. O. (2013). Innovatsiino-investytsiina i tekhnolohichna bezpeka transformatsii rehionalnykh ekonomichnykh system [Innovative-investment and technological safety of transformation of the regional economic systems] : monohrafiia. Kyiv : Naukovo-vyrobnyche pidpryiemstvo «Vydavnytstvo «Naukova dumka» NAN Ukrainy» - A scientific and production enterprise is publishing "House "Scientific thought" to HAH of Ukraine" , 487 [in Ukrainian]. 